\title{
Ideas and impact: Continuity, change and constraints in the institutional landscape of Curaçao, Sint Maarten, and Trinidad and Tobago
}

\author{
Genève Phillip-Durham \\ Institute of International Relations, University of the West Indies, Trinidad \\ Geneve.phillip@yahoo.com (corresponding author)
}

\begin{abstract}
In the context of Caribbean small island jurisdictions, a picture has customarily been painted of bloated bureaucracies, the prevalence of state institutions in the mechanics of governance, institutional weakness and a lack of institutional innovation. We argue that particularistic claims about enduring institutional structures and behaviours have not come about in a vacuum. Our core contribution is toward Caribbean comparative scholarship from an institutional standpoint, whereby we utilize selected aspects of a constructivist theoretical framework, together with a Most Similar Systems Research Design. The findings and analysis are based on the triangulation of secondary data and primary data collected in 2015, via a series of elite interviews conducted in Curaçao and Sint Maarten, two Subnational Island Jurisdictions (SNIJs); and Trinidad and Tobago, an independent Small Island Developing State (SIDS). The primary thrust of our debate is to articulate the position that much of what obtains in public institutions in the Caribbean has been shaped by patterns of ideational diffusion and norm formation, which can be traced to colonial experiences. We grapple with this notion by exploring, inter alia, the sociopolitical heritage and continuity and change within the institutional structures of the named islands.
\end{abstract}

Keywords: bureaucracy, Caribbean, colonialism, diffusion, ideas, institutions, norms

https://doi.org/10.24043/isj.113 • Received June 2019, accepted January 2020

(C) 2020 - Institute of Island Studies, University of Prince Edward Island, Canada.

\section{Introduction}

Prior to October 10, 2010, Curaçao and Sint Maarten were part of a unitary federation known as The Netherlands Antilles, within the Kingdom of The Netherlands. This complex political and constitutional arrangement meant that Curaçao and Sint Maarten have traditionally been subsumed into studies with all the other territories of which the former Netherlands Antilles comprised: Bonaire, Saba and Sint Eustatius. The tenuous and often controversial relationship between The Netherlands and its Caribbean overseas territories culminated in a series of referenda, which became necessary in order to determine the future political and constitutional status of the aforementioned territories. By 2010, political reform within the Kingdom resulted in the dismantling of The Netherlands Antilles, making it both possible and practical to examine Curaçao and Sint Maarten as entities in their own right, as both 
became separate constituent states on the occasion of 10.10 .10 (10 October 2010) and were therefore no longer part of the unitary federation.

Trinidad and Tobago, on the other hand, is a former British colony which has been independent for more than 50 years. This Small Island Developing State (SIDS) has not typically been studied alongside non-independent, non-Anglophone Caribbean island territories, some of which are Subnational Island Jurisdictions (SNIJs). Although the twinisland republic has been independent since 1962, it remains uncertain as to the extent to which this status categorically and distinctively sets it apart from its non-independent counterparts. At the outset, the cases for comparison are seemingly diverse polities. However, we utilize a Most Similar Systems Design (MSSD) which is preferred by qualitative researchers who are interested in identifying key features that are different among similar countries, with a view to clearly understanding what might be able to account for a particular observed outcome (Landman, 2008). Our case selection, therefore, is based upon the premise that although they may seem diverse polities, they are sufficiently similar by virtue of their size, colonial experience and geographic location, and sufficiently different in terms of their economic trajectories and constitutional and political status, for us to be able to engage in some meaningful discussions regarding the implications of these factors for continuity and change in Curaçao, Sint Maarten, and Trinidad and Tobago.

Furthermore, our epistemological agenda is to tease out how ideational diffusion impacts upon knowledge creation and sense-making in relation to selected institutions in the small island territories of Curaçao, Sint Maarten, and Trinidad and Tobago. Our survey of the literature points toward several multi-country and or quantitative comparative studies on SIDS and SNIJs in general. Relevant examples include the comparative research undertaken by Hyden, Court and Mease (2004) on Making sense of governance: Empirical evidence from sixteen developing countries and Exploring sub-national island jurisdictions by Baldacchino and Milne (2006). However, we observe that studies which adopt a qualitative and comparative approach to understanding island-specific challenges related to the institutional landscape of different categories of Caribbean small island territories are limited. This has led us to focus our analysis on this region. That said, factors including their historical, sociopolitical and constitutional status lend themselves to a new wave of comparative research on the institutional landscape of independent versus non-independent Caribbean small island territories. Similarly, it is worth noting the theoretical leverage that may be afforded by the constructivist approach and, as such, we consider it sensible to draw upon the concepts of ideational diffusion and norm formation, which we deploy as the investigative tools in our analysis.

We are particularly interested in ideational push and pull factors, norms and conventions about norms, as well as differences and similarities in their influence and impact. Thus, our primary research question is: What are the implications of ideational diffusion and norm formation for institutional outcomes and continuity or change in different categories of Caribbean small island territories? In order to answer this question, we embarked upon a qualitative research exercise, conducting a series of elite interviews within the public sector, private sector and civil society in Curaçao, Sint Maarten, and Trinidad and Tobago. We then transcribed and corroborated the responses from semi-structured interview questions, with the secondary literature surveyed on diffusion, norms and Caribbean institutions. The structure of the paper is as follows. We begin by examining the concepts of ideational diffusion and norm formation as possible tools of domination; secondly, we look at norm interpretation 
and institutional adoption in the Caribbean region; thirdly, we provide empirical illustrations from both the Dutch and Anglo-Caribbean contexts; fourth, we examine ideational power and institutional shifts; and fifth, we contextualize some of the capacity constraints that have persisted over time. By way of conclusion, we summarize our findings on the systematic and structural effects of ideas and norms in the institutional landscapes of the territories under study.

\section{Ideas and norms: Tools of domination?}

Diffusion can be classified as the spreading of something extensively or more widely. When we think about diffusion, it is not unusual to envision it as a scientific kinetic molecular process. It should be noted, however, that diffusion is not solely confined to natural science boundaries, and its usage has gained prominence in several disciplines within the realm of social sciences. According to Gilardi (2012, pp.454-455), while "the systematic analysis of transnational diffusion processes is relatively recent," it has steadily gained prominence and now lies at the "core of some of the most important debates in international relations." Applying the concept to international relations scholarship, Lenz (2013, p.213) states that "diffusion denotes the spread of norms, ideas, institutions, policies and practices in time and space." He goes further to highlight one of the central claims advanced by diffusion scholars: that the decisions in one unit of analysis often tend to systematically and/or structurally affect the decisions taken in other units (Lenz, 2013).

A similar line of scholarship states that ideational diffusion "connotes spreading or dispersion of models or practices from a common source or point of origin" and further characterizes it as "a trend of successive or sequential adoption of a practice, policy or programme" (Stone, 2012, p. 484). Conceptualized in this manner, it is clear that, for diffusion to take place, two or more actors must be involved: someone who diffuses an idea, belief or philosophy and someone who is the recipient of that which is being diffused. Lieberman (2002, p.700) further notes that "the important point is not only where ideas come from or how they cohere or collide but also how they come to be prominent, important, and powerful, even determinative in shaping political behaviour and defining political rationality." The motif of power in the diffusion literature is evident. We believe that power relationsnot only between states but between states and multilateral agencies which participate in global agenda-setting - have considerable implications for the determinative and influential capacity of the ideas which they advance and support. One of the critical claims we therefore make is that ideational diffusion and norm formation are not only contingent upon the factors of time and space, but audiences also play an important role in determining the extent to which normalization takes place.

When ideas become normalized or institutionalized, they have the potential to become "tools of domination" (Beland, 2010, p. 149). Whether they are seen as mutually constitutive or as one being a by-product of the other therefore becomes irrelevant for the understanding we wish to convey about their fundamental impact and influence. According to Lenz (2013, p.216), "normality can be defined as the intersubjective recognition of certain norms and ideas as unquestioned, taken-for-granted facts." Another way in which norms are viewed in the academic literature speaks to the process of norm formation. Gallagher (2014, pp.332333), for example, rationalizes in the following way about norm forming: "Norms become ideal when they are able to conflate what is good with what is appropriate, standard, or proper. 
It is when the good becomes 'natural' that a norm appears immanent and non-contestable, and so acquires an idealized form." Defined as such, a core element of norms is their apparent neutrality, which forms the basis for their acceptance and or reproduction in different contexts. Norms are inherently regulative and may function as a constraint on certain activities, may serve to disrupt certain activities or behaviours, or may stimulate the adoption of certain behaviours based on their orientation.

Many of the contemporary constraints and opportunities in the realm of Caribbean small island territories can be attributed to the historically constructed institutions which have endured over time in their original or adapted formations (Beland, 2009). Due to the impracticability of exploring the gamut of institutions which exist, we focus on what we consider to be two of the most fundamental institutional inheritances in many Caribbean small island territories: the bureaucracy and parliamentary system. Emphasis is placed on these specific institutions of which the overall governance machinery is comprised, as we believe they are best able to capture in sum or in part the significance of the methods of diffusion identified in Table 1, in relation to the politics and history of the islands.

Table 1. Modes and methods of diffusion. Source: Adapted from Towns (2012, pp. 184-185) and Lenz (2013, p. 213).

\begin{tabular}{|l|l|}
\hline Modes & Characteristics \\
\hline Socialization & $\begin{array}{l}\text { This diffusion mechanism is characterized as ideational, active. It } \\
\text { occurs via channels such as cooperation agreements, political dialogue } \\
\text { or technical assistance. }\end{array}$ \\
\hline Learning & $\begin{array}{l}\text { This diffusion mechanism is characterized as ideational, passive. It } \\
\text { occurs via channels such as successful integration of a } \\
\text { discourse/narrative, symbolic representations. }\end{array}$ \\
\hline Mimicry & $\begin{array}{l}\text { This diffusion mechanism is characterized as ideational, active. It } \\
\text { involves gaining new beliefs about proper ends and about casual } \\
\text { relationships. Lessons are drawn from actively reflecting on changes in } \\
\text { other countries. }\end{array}$ \\
\hline $\begin{array}{l}\text { This diffusion mechanism is characterized by automatic emulation. It } \\
\text { is common for cues from the external environment to have impact and } \\
\text { influence without much reflection or debate in the internal } \\
\text { environment. }\end{array}$ \\
\hline
\end{tabular}

\section{Repeating islands: Norm interpretation and institutional adoption/adaptation}

The bureaucracy and parliamentary systems which exist in many Caribbean territories today represent an important aspect of the region's shared colonial history, as well as the "tacit acceptance of the political institutions of departing colonizers" (Corbett \& Veneendaal 2016, p.8). Commenting on the proneness to mimic metropolitan institutions, Veneendaal (2016, p.1) notes that it is not "atypical for small island territories to adopt political institutions with which they have become familiar as a result of formative colonial relationships." In his assessment of this pattern of behaviour, Girvan (2015, p.97) takes the notion of tacit acceptance a bit further, suggesting that "implanting of colonial ways of thinking into native 
elites was one of the outstanding successes of British policy in the Caribbean. It was key to the entrenchment of the Westminster government." In Trinidad and Tobago, for example, the system of governance follows a variation of the Westminster model of the United Kingdom, with which a colonial relationship once existed. The effectiveness of the socialization and learning which beget the trend of tacit acceptance is clearly conveyed in the early expressions of the political leadership of Jamaica, and Trinidad and Tobago, respectively, the first two islands in the Anglophone Caribbean to attain independence from the United Kingdom.

Converging with similar findings of Girvan (2015) and Veneendaal (2016), when we revisit the works of Lindsay (1975) from some decades earlier we see the entrenchment of norms based on the sponsorship received from the political leadership within Caribbean small island territories. For example, Jamaican politician Norman Manley expressed his pleasure with the fact that Jamaica could still make use of the institutions of Westminster-style government, and Trinidad and Tobago's Prime Minister Dr. Eric Williams similarly conveyed that if the latter was good enough for England, it was good enough for Trinidad and Tobago as well (Lindsay, 1975). The crux of the matter with which we are concerned here is the repetition of these types of behaviours which reinforce patterns of diffusion that render the normative agenda difficult to resist or reject by virtue of the valence they take on, due to the sponsorship they receive from the political elite in a given territory.

While we argue that the degree of continuity supersedes the degree of change in the institutional architecture of both independent and non-independent jurisdictions, Payne (1993) suggests that change rather than continuity was most notable in terms of the creative adjustment and adaptation of the Westminster model, which resulted in what he refers to as its 'Caribbeanization'. Notwithstanding, Payne (1993) simultaneously notes that the main tenets of the Westminster system had largely survived in recognizable form throughout the British Caribbean-something which we will delve into a bit further in order to understand why that has been the case and what have been the underlying implications.

By the same token, in Curaçao and Sint Maarten, a consociational model, which replicates that of the Netherlands, transitioned into the post-autonomous era. Consistent with the consociational model, norms associated with proportional representation and power sharing became the hallmark of the governance machinery in both Curaçao and Sint Maarten. However, instead of facilitating equilibrium and stability, some implications of adherence to the model included frequent changes in administration due to consecutive government collapses, lengthy periods of negotiation among political parties regarding the formation of governments and difficulties in managing power sharing (General Audit Chamber, 2014). The foregoing scenario, which became characteristic of the post-autonomous era, thus painted a picture of the inappropriateness of the consociational model for these respective contexts. Consideration of some of the policy documents, media reports and sentiments expressed in national discourses indicate this perceived inappropriateness of the consociational model for, among other things, guaranteeing political stability in the islands of the former Netherlands Antilles. By way of illustration, we present examples which help us to understand the applicability of the diffusion mechanisms of learning, socialization and coercion in realworld scenarios.

In considering what constitutes learning and socialization, our first scenario which captures the challenge with government formation presents a fitting example. While in a theoretical sense the consociational model was designed to facilitate representativeness and 
stability, in a practical sense it has been pointed out that in the case of the Netherlands, "forming a government is very complicated because many parties are represented in parliament. Bargaining can take months [...] Because of the problems that might arise, there have been many different proposals to change [...] until now to no avail" (Netherlands Institute for Multiparty Democracy \& Instituut voor Publiek en Politiek, 2008, p.38). In the Sint Maarten and Curaçao contexts, the learning and socialization which has taken place in relation to this model has resulted in undue delays in government formation each time the government collapses because, just as occurs in the Netherlands context, "the political composition of the government depends more on post-election bargaining than on the actual election results" ((Netherlands Institute for Multiparty Democracy \& Instituut voor Publiek en Politiek, 2008, p.43). A recent example can be cited in the case of Sint Maarten, where a caretaker government existed for more than six months following the government collapse after Hurricane Irma. The major point to be illustrated here is that there is a domino effect on institutional effectiveness, capacity and continuity when there is a delay in government formation, exacerbated by the inability of a caretaker government to make concrete decisions or pass laws via processes which are typically deliberated within institutions of the state.

A former member of parliament interviewed in Curaçao expressed the view that the pattern of institutional adoption witnessed in territories with a colonial history was not a practice to be celebrated or commended. That perspective was explained as follows:

Our history is not something we chose, but it is something that will always bring us together. Being from the Dutch Kingdom we have a lot of institutions which are Dutch [metropolitan] and for me not all of them fit, and that puts us in a troublesome situation in many instances. We have a lot in common with our own surroundings, but these institutions' influence on us is so minimal that we do not get to converge and share ideas with our own regional neighbours.

Another research participant echoed this view: "At the island level, we have reached over 50 types of coalitions [...] We don't have a stable democracy [...] We have had in the last four years, four Prime Ministers [...] With every change of person, there is change in policy [...] Imagine where we are as a country with such instability." We argue that the diffusion of ideas and norms in relation to institutions is important because they have a constitutive impact on institutional behaviour and, more specifically, on institutional stability or the lack thereof. Our empirical data also highlights a key constructivist premise about ideas all the way down because we see that what matters is not solely the adoption of an idea but the structural impact that the idea has within a given institutional context (Hopf, 2000).

We now turn our attention to efforts at constitutional reform, meant to curb the practice of ship-jumping, to which government instability in Sint Maarten could be attributed.

Ship-jumping, the practice whereby representatives of political parties could switch allegiance in the post-election bargaining process to form part of the government, became normalized in the post-independence era. According to former Prime Minister WescotWilliams, "In every case of jumping ship we have seen in our short country status, the result has always been a new government formation with mostly new ministers" (Today Newspaper, 2016, n.p.). Notwithstanding the expressed desire for change in the constitution to address this practice, then-Dutch Minister of Home Affairs and Kingdom Relations Ronald Plasterk 
stated that "The Kingdom Government has serious objections to the proposed change to the St. Maarten Constitution to tackle the so-called ship-jumping of Members of the St. Maarten Parliament, and has urged the St. Maarten Government to address these concerns" (Daily Herald, 2016, n.p.). Addressing these concerns meant that electoral reform, which was an "essential mandate of the Marlin cabinet by virtue of the Governor's instruction and the government's own election decree," according to Wescot-Williams (Today Newspaper, 2016, n.p.), did not become a reality, and alternatives to constitutional reform in order to address the negative chain reaction caused by ship-jumping have since remained unclear.

In spite of the deficiencies exhibited by the Westminster model which can be found in the greater Caribbean, it is noteworthy that, in terms of political stability, it has been of greater utility to the Anglophone Caribbean than has been the consociational model for Curaçao and Sint Maarten (Bishop, 2011; Girvan, 2015; Veneendal, 2016). For instance, a senior politician highlighted the way in which intervention from the Netherlands exacerbated the already deficient institutional landscape in Curaçao in the post-independence period, by ousting the then-prime minister:

The Schotte administration was forced out of power by the Dutch in 2012 so we had to start from scratch with an interim cabinet which had three months to get things right $[\ldots]$ After that $[\ldots]$ some extremely difficult measures had to be taken [...] This entailed another six months of working toward specific targets, and after six months a new set of ministers would once again be instituted.

In Trinidad, on the other hand, a similar level of parliamentary instability was not observable. One research participant did, however, express disappointment that "We tend to adapt to the Westminster governance. We often cut and paste and oftentimes, when laws are created, there are not supporting policies. What we have is a cut-and-paste law with a lot of loopholes, and it puts us in a bad position in terms of governance." Although the Westminster model was not representative in orientation, it yielded a greater degree of institutional stability than did the consociational model, which, based on our interpretation of the empirical data, had not worked in the best institutional interests of either Curaçao or Sint Maarten.

Like the parliamentary models, the bureaucracy continues to be an enduring feature of many postcolonial and post-autonomous institutional settings. Stemming from the colonial period, it was not uncommon for structural hierarchies such as the bureaucracy to occupy a prominent role in overall governance and administrative procedures. Bureaucratic institutions were used not only to facilitate public administrative processes but also as a symbolic tool for reinforcing order and power. At the time that independence was granted, newly independent countries, such as Trinidad and Tobago, were presented with the opportunity to pursue development goals and build human and social capital to leverage their newly acquired political status to yield maximum benefit (Beckford, 1972; Best \& Levitt, 1969). Though Payne's (1993) Westminster Adapted presents a Caribbeanization of the Westminster model, Quinn (2015, p.1) argues that "independence consolidated political institutions and norms based on Britain's Westminster model of government," the shortcomings of which became a source of public concern in Trinidad and Tobago immediately following independence. For example, one politician interviewed suggested that it "facilitated a dictatorship," while another research participant lamented that it centralized power in the hands of a few, limiting 
the scope for representative participation. Given these concerns, the question might be asked: why did the colonial bureaucracy and Westminster parliamentary model become prominent features of Trinidad and Tobago's postcolonial governance framework?

Girvan (2015) argues that, irrespective of whether there have been wide-ranging or modest attempts at constitutional reform in islands states such as Saint Vincent and the Grenadines and Trinidad and Tobago, the major concerns regarding the Westminster system have not been addressed, as, among other things, weak local government and unchecked executive power have persisted. Similarly, we may wish to ask why the consociational model has been retained in post-autonomous Sint Maarten and Curaçao despite the evident constraints it presents for the maintenance of political stability, as can be gleaned from the most recent examples of the collapses of government in Curaçao (2017) and Sint Maarten (2017 and 2019)? In the following section we explore the themes of continuity and change amidst consistent constraints.

\section{Continuity amidst consistent constraints: Illustrations from the Anglophone Caribbean}

Normative push factors have had implications for the degree of continuity and change observable in many postcolonial institutional contexts. In the view of La Guerre (2012), 'good governance' became the preoccupation of countries in the Anglophone Caribbean in the postindependence era and was equated with preserving the status quo while simultaneously curtailing any rapid movements toward a changed governance landscape. Alternatives to this norm were not pursued, but new bureaucratic institutions were instead created as an expression of individual egos, and existing bureaucratic institutions were expanded (Ghosh, 1996). From the 1980s, Caribbean countries began efforts at reforming the bureaucracy by embracing New Public Management doctrines, which aimed at improving efficiency and privatizing state services, but actual reforms have been minimal (Bissessar, 2002). However, in the case of Trinidad and Tobago, in spite of the institutional transplantation of the bureaucracy and the learning and socialization which sustained it, its postindependence composition is easily distinguished from what existed during the colonial period.

La Guerre (2002, p.24) notes, for example, that in the transition from colonial rule to independence, governance became an affair for local elites "who claimed to have the answers to all the problems of governance," while, for the masses, "governance was about what government could give them." This is the backdrop against which the clientelism that followed developed. Thus, what distinguished the postindependence bureaucratic model from its predecessor was the relative absence of personnel who would wield their colonial power or influence, as bureaucratic institutions became vehicles via which rewards could be granted by the incumbent local political elite to individuals who supported them in the electoral process (La Guerre, 2002). According to Arthur (2002, p.35), it could therefore be argued that the bureaucracy became a key component of the "patronage and spoils systems which work against sound and progressive government" since it was being used as a tool for political domination and nepotism by local political elite and high-level administrators.

According to Turner, Hulme and McCourt (2015, p.2), as time progressed in several postcolonial developing countries, there was "ample evidence of dysfunctional bureaucracies avidly devouring scarce resources but failing to produce anticipated outcomes." Likewise, 
with the bureaucracy as one of the major institutional pillars and a lack of "genuine interest in systematic administrative reform," Trinidad and Tobago was no exception to other countries throughout the independent Caribbean region that shelved major recommendations for reform within the bureaucracy (Ryan, 2002, p.452). One political leader interviewed in Trinidad confirmed this view, as disappointment was expressed regarding the fact that those who were in positions of power and responsible for governing and creating an environment to drive development were slow to acknowledge that "the institutional landscape needed to be revisited." In light of these observations, we concur that preservation of the status quo within the bureaucratic machinery, which was characteristic of the immediate postindependence era, transitioned well beyond that period. Though acknowledged as problematic by consecutive political regimes, challenges with bureaucratic capacity have endured.

\section{Continuity amidst consistent constraints: Illustrations from the Dutch Caribbean}

When we examine the institutions that currently exist in Curaçao and Sint Maarten, the bureaucracy, judiciary and parliament are all colonial inheritances which were retained in the post-dissolution era. In addition, Dutch was retained as the official language of public institutions. This is particularly relevant to this discourse since English is the predominant language of communication on the island of Sint Maarten and Papiamentu on the island of Curaçao. As a result, much of the workforce of Sint Maarten was severely constrained in their ability to effectively execute their duties due to their limited command of Dutch. Unlike in the case of Trinidad and Tobago, where the political elite were to a large extent able to shape the postindependence sociopolitical context (albeit by clinging to colonial norms, ideas and models), many metropolitan technocrats and civil servants either remained on the island or were recruited to assist with Sint Maarten's smooth transition to a country (Girvan, 2015; Ryan, 2002). In Curaçao, on the other hand, having been the administrative hub of The Netherlands Antilles, fewer linguistic constraints were apparent. In fact, although Curaçao inherited a parliamentary structure that was closely modelled after that of The Netherlands, parliamentary proceedings are conducted in Papiamentu, a language that is indigenous to Curaçao.

Curaçaoans have nevertheless typically been more versed in Dutch than have their autonomous counterparts, which has enabled them to adapt much more quickly to the postautonomous institutional landscape in terms of their understanding of the legal language and governing decrees. Commenting on this, one Senior Administrator in Sint Maarten who had previously worked in Curaçao, noted that, "unlike with Curaçao, we knew that there would be challenges for Sint Maarten because of language. It is difficult for us to produce our own capacity so there is a need to bring people from abroad to assist with the development." Concurring with this point on the implications of language for capacity, an attorney explained the challenges as follows:

If you look at the institutions, the formal legal language is Dutch, and not everybody masters the Dutch language. I think Sint Maarten is therefore still quite dependent on Dutch technical assistance, and that doesn't only have to do with the language, but they don't have knowledge in-house. So you can say that they want to do everything themselves, but I don't think they're capable of doing that. In my law 
practice, if I take up a case against government, I always start by the rule of law, and many times it always goes wrong there, so that's what I start with always.

Still, there has since been little to no role for institutions like the media, private sector and civil society in becoming actively involved in the governance process. Furthermore, representatives of these institutions have lamented how the importance of their respective roles and input is often undermined and obscured by the processes and procedures supported by norm entrepreneurs, who tend to be high-office holders within the government apparatus and bureaucracy itself. One political advisor and entrepreneur in Sint Maarten remarked, "To expect the beneficiaries of a broken system to change it is unrealistic. Government uses some institutions $[\ldots]$ to punish people $[\ldots]$ They may use the bureaucratic machinery to withhold business licenses [...] punish media by withholding advertisement opportunities." The size of Sint Maarten made the propensity for personalized politics much more distinctive than for a larger jurisdiction and also increased the possibility for conflicts of interest to arise in a context in which it was common for political elites to have familial or friendly ties with the citizenry.

By examining two of the most fundamental colonial institutional inheritances, we have attempted to convey how diffusion mechanisms of learning and socialization may facilitate continuity within these structures. The entrenchment of personalized politics, winner takes all, ship-jumping and patronage, and the disequilibrium and discontent these phenomena engender, is illustrative of the need to interrogate the operative contexts which have given rise to them.

\section{Ideational power and its implications for institutional shifts}

Material power on its own is an insufficient means of influencing institutional outcomes and behaviours but instead ought to be considered a precondition or prerequisite for soft or ideational power and the ability to mobilize support for specific ideas and norms in the contemporary global setting. The basis of our argument is that though material power has traditionally been used to reinforce the position of influential states in the global system such as the United States and EU Member States, there has been a shift in the overall power structure of the global system whereby old structures of material dominance have been eclipsed and or supplemented by ideational ones (Holm \& Sørensen, 1995). In our effort to align this observation with the broader concerns of this paper, we want to look at the way in which soft or ideational power in its own right impacts upon institutional behaviour and the behaviour of persons who are responsible for leadership and governance of these institutions.

\section{Trinidad and Tobago}

The idea that the bureaucracy would serve to drive development in the postindependence and post-autonomous eras proves to be an erroneous assumption based on what was experienced in the Trinidad and Tobago context (Demas, 2002; Dumas, 2002). By the end of the first decade of independence for many Caribbean countries, the success of bureaucratic institutions was relative, if at all distinguishable, confirming the view that many universalistic ideas as they relate to governance and governing apparatus may be unworkable and even undesirable in some postcolonial settings (Turner et al., 2015). As expectation failed to meet reality with the independence dream, and it became increasingly challenging for countries to 
stabilize their economies, a period of reform followed, requiring many newly independent countries to revisit their accelerated nation-building ambitions.

The ideational shift in terms of the appropriateness and relevance of governing apparatus was followed by the promotion of an institutional shift which would closely resemble that which exists in a private-sector setting, with the advent of New Public Management (Manning, 2001; Pollitt, 1993). In Trinidad and Tobago, for example, during the period when appropriate governance norms were being discussed within a reforms framework, one of the major initiatives that came to the forefront of the reform agenda was the transition from a Weberian bureaucratic structure to New Public Management (NPM). NPM was intended not only to stimulate the better functioning of the bureaucratic machinery by curtailing its size but also to address the shortcomings of the system inherited and the threats to good governance that were ubiquitous during the postindependence period (Oostindie \& Sutton, 2006, p.29). However, though the newly attained affinity to a privatized way of doing business was meant to manage maladministration and inefficiency, it challenged a status quo which served the interests of some well-placed technocrats and political elite (Bissessar, 2002). This was primarily because the advent of NPM involved significantly curbing the size of the bureaucracy, which would hinder the latter's usage as a vehicle of patronage.

Our historical analysis of the bureaucratic machinery highlights challenges not only with patronage but also with inefficiency and maladministration. In spite of efforts toward reform by way of NPM, our analysis of the contemporary context illustrates that many of the same institutional challenges have persisted and, in some cases, have become more pronounced over time. One senior politician shared a fitting example, attributing maladministration to the:

Cumulative inefficiency of the system of governance that has become ingrained since the postcolonial period [...] I just received a document to sign for a decision to be taken on an employee, and based on the date, it suggests that this document has been in transit for signature for the past four years! That employee is no longer even in the system.

What this suggests is that although ideational shifts may have catalyzed initial efforts toward institutional shifts and changes within the context of SIDS such as Trinidad and Tobago, institutional behaviours had not necessarily adjusted to reflect the success of a particular ideational or normative dynamic as relates to ideas about NPM. Essentially, the embedding of behaviours from the traditional bureaucratic structure highlights how structural and systematic changes are contingent upon the intersubjective meaning that actors ascribe to historical processes and patterns. Thus, while it became clear that the bureaucracy in its prior format was not an economically viable option, and therefore the principles which governed its structure needed to be changed, the disposition toward the institutional environment remained relatively stable and manifests itself in what is experienced by way of efficiency and effectiveness, or lack thereof, in the contemporary bureaucracy.

\section{Curaçao and Sint Maarten}

When autonomy was granted to Curaçao and Sint Maarten by the Netherlands in 2010, there were great expectations locally in terms of what this new status would mean for the territories in a practical sense. One of the primary expectations was that there would be a less prominent 
and powerful role for the metropolitan Netherlands within the confines of these jurisdictions. However, the subsequent struggle for internal power and control which ensued following the dissolution, coupled with the use of the bureaucracy as a tool to reward political loyalists, eventually resulted in increased oversight from The Hague, thereby reigniting the "long history of mutual disregard and antagonism" (Oostindie \& Klinkers, 2003, p.63). To an extent, the principle of non-interference in relation to autonomy was legally enshrined in the Kingdom Charter, "thus largely preventing Dutch political intervention" (Veneendaal 2015, p.20). However, the fact that the guarantee of human rights and good governance were Kingdom responsibilities and were perceived by the Netherlands as being ineffectively managed in the territories "resulted in a yearning for more political tools to intervene in the case of perceived problems in the sphere of good governance" (Veneendaal, 2015, p.20).

In the case of Sint Maarten, one interviewee suggests that the experience was such that, in addition to the ideational push from their respective metropoles, European overseas territories were also impacted by and expected to respond favourably to ideas and norms which diffused from multilateral and global governance institutions. The situation described by one interviewee as "re-colonization" was explained in detail as follows:

Holland's action toward Sint Maarten is more than colonization. Holland is losing its influence in Europe in general. It is one of the smallest countries in the EU, so the only way they can retain its power is by controlling these colonies and using them to wield power. When it's convenient to say we are equals within the Kingdom, they say it. But we are not equals within the Kingdom because the Council of Ministers is all the Ministers of the [metropolitan] Netherlands and one of each of the [Antillean] islands. Why do other world leaders get to decide what is acceptable and what is not, and when we do it, it's a problem?

What was distinctive about this interview was the fact that the research participant, who held a ministerial portfolio, admittedly expressed a lack of enthusiasm regarding the execution of duties due to the frustration and constraint experienced in attempting to make decisions autonomously and free from input and interference from The Netherlands. The latter represents an appropriate example of the view that "non-sovereign status entails that politics in overseas territories is to varying degrees, supervised and constrained by the metropolitan government" (Veneendaal, 2016, p.261).

Likewise, in Curaçao, the possibility of heightened supervision from metropolitan Netherlands in the near future remains a possibility against the backdrop of yet another collapse of parliament and, by extension, government. Such scenarios are inextricably linked to the challenges with colonialism and conformity, as the frequent collapses of government can be attributed to the inappropriateness of the parliamentary system inherited, as we have demonstrated thus far based on the empirical data collected. Apart from voluntarily retaining some of the institutional mechanisms such as the parliament and bureaucracy from the metropole, some of the regulatory bodies and institutions that have been set up continue to be forced or imposed upon the post-autonomous communities, resulting in much frustration. In relation to this, one research participant in Sint Maarten expressed the view that "we do not lack for proper institutional structures, albeit we may have copied a bit too much of a European system without taking into account our own unique situations." In light of this, the expectation of 
conformity with colonial inheritances continues to undermine efforts to innovate institutions that are much needed to address the institutional deficits in both Sint Maarten and Curaçao.

An institutional shift toward private-style arrangements, as was the case with Trinidad and Tobago in the era of institutional reform, is yet to gain momentum in the constituent states of the former Netherlands Antilles. It is interesting to note, however, that institutions that are meant to protect against abuses in the public sector and within government, such as the Ombudsman, General Audit Chamber and Council of Advice, have come about much more quickly than have similar institutions in their independent counterparts. Still, this has not been enough to convince power brokers in The Hague that ongoing suggestions for the intensification of instructions on the islands can be limited. For example, one of the most notable interventions has been the pursuit of the installation of a Quartermaster in Sint Maarten to establish an Integrity Chamber, citing incessant integrity issues.

Some research participants shared that, when it comes to the management of institutional affairs, the instructions and supervision were not always unwarranted, since there was an evident lack of initiative taken to implement self-correcting measures. In an interview with someone from the Department for Interior and Kingdom Relations, for instance, the following was shared: "We are not functioning, and there are many reasons why we cannot function. For some personnel within the civil service, it has become acceptable to be dysfunctional, and that's a big problem. Sometimes it feels like people are motivated to keep the system dysfunctional." The inconsistency with regulation in the civil service and the lack of adherence to correct procedures and practices is also highlighted in a report produced in Sint Maarten entitled Baseline study institutional integrity management (General Audit Chamber, 2014). In that report, references are drawn to "no valid implementation rules" within some sectors of the civil service and a need for an all-encompassing and relevant inquiry in order to manage institutional challenges (General Audit Chamber, 2014, p.24). In order to manage institutional challenges, an increase in the technical know-how, capacity and agency to make the necessary structural changes would be required. We focus on these in the subsequent section.

\section{Contextualizing capacity constraints}

The institutional scenario in Curaçao following the dissolution of The Netherlands Antilles was such that policymakers at the island government level were confronted with a lack of technical know-how to adjust and adapt to many of the conditionalities laid out by The Netherlands. The lack of human and institutional capacity therefore had implications for Curaçao's ability to resist or reject these conditionalities. More importantly, if technical assistance from The Netherlands was resisted or rejected, this would mean that Curaçao would require the necessary financial wherewithal to invest in capacity and institution building. This was not a possibility in the post-autonomous context.

In light of the financial shortcomings that were characteristic of the post-autonomous era, one academic who focuses research efforts on transparency and integrity in Curaçao suggested that that "It is nice to have our own institutions, but we are so small some things are weird to organize separately because it costs a lot of money. We're still struggling in terms of how we're going to manage with all these things." A Director at the Ministry of Economic Development, who was deeply involved in the post-dissolution institutional adjustment process, further contextualized the challenges being experienced in the following way: 
We had to hire a lot of people from abroad to get things going, people with expertise to help us in the process. 3.2 million guilders was spent to hire consultants to help us with nine policy projects. Things that were stuck, we were able to finish them. The challenge was the lack of expertise and human capacity.

While the Ministry benefited from hiring personnel to complete tasks, the fact that these people were consultants who would ultimately depart with much-needed institutional knowledge and technical know-how meant that there was little to no opportunity for knowledge transfer to occur, especially given the consultants' time constraints.

The inefficient and unresponsive nature of some institutions was further compounded by the prevalence of state institutions in the mechanics of governance. This has in some instances negatively impacted the political economy of development in some island territories. This situation is especially true for Sint Maarten, which relies substantially on revenues earned from the tourism industry. One person who retains a leadership position within the Sint Maarten Hospitality and Tourism Association shared the following: "We should have by now more developed institutions in place. If we really want to push things forward, we need to implement things. We lose so many investors because things move so slowly." Another interviewee attributed the tardiness with which tasks were executed to the newness associated with building a new country. Speaking based on experience, having worked with the Department of Interior and Kingdom Relations both pre- and post-dissolution, the interviewee remarked that: "After 10.10.10, there were few institutions in place, so we had to build them from scratch. My main focus after 10.10 .10 was institutional building and awareness. A major challenge is that things go slow because people know so little about how they should function." Thus, pervasive institutional weakness in the former Netherlands Antilles has been the hallmark of many of the discourses and debates initiated by metropolitan Netherlands and has served as a primary justification for interference in the islands' internal political and institutional affairs.

Meanwhile, in spite of its history as an independent and sovereign nation, the commentary offered by some research participants did not paint a much different picture of what the institutional scenario in Trinidad and Tobago looked like. A case in point is the view shared by the CEO of one of the most influential media entities in Trinidad and Tobago: "There is a greater need for institutions that work to correct governance failures, not governmental ones. All institutions need to converge in order to assist in the process, but I think we have a long way to go. Our institutions don't function, and no one wants to admit we have a capacity issue." It should be noted, though, that attempts have been made to stimulate interest in constitutional reform since 2001 in Trinidad and Tobago in order to address some of the common challenges that have been noted here.

Possession of the capacity to plan, coordinate and implement decisions that would work to address institutional failures and institutional incapacity was echoed by one of our research informants, who was previously an employee of the World Bank Group, Trinidad office: "One of the biggest challenges is the capacity within the bureaucracy and even parliament. I saw things got choked up because of a person's inefficiency or because of a bill they let sit in parliament for years and not debate it." While it was evident based on our triangulation of interviews and public discourse that there was a lack of capacity and trust in institutions and 
the highest office holders within them, there was no indication that this informed the need or desire for institutional realignments or reconfigurations.

The fact that the state for the most part continued to be the main driver of development even in the aftermath of the era of institutional reform and New Public Management in Trinidad and Tobago meant that the structural responses in relation to capacity building and strengthening had to originate from within state institutions. When we compare the views expressed by research participants across territories, the commonalities in relation to policy development, capacity building, institutional (in)efficiency and implementation are crosscutting themes that could be collectively addressed.

\section{Conclusion}

It has become increasingly important to tease out the critical issues pervading debates on ideas and norms and their respective impacts on the institutional arrangements in political, social, cultural and economic settings that differ from metropolitan contexts. Research participants have expressed concern about the absence of enquiry into precise approaches and challenges that originate within island contexts. An economist in Curaçao, for example, lamented that "most of the research is conducted in well developed, large countries, and then we take those textbooks and teach our students what to do according to the institutional frameworks that work in other countries and not on this island." Veenendaal's (2016, p.1) argument in relation to the autonomous Dutch island territories seems to be substantiated: "As long as institutional reforms that better reflect the small island context continue to be shunned, political instability in the Dutch Caribbean will endure."

The quality and functioning of institutions in small island networks is largely based on how politics, history, culture and value systems inform them. This is primarily applicable to public institutions since they still play such an important role in driving the development agenda. As a result of the learning, emulation, socialization and mimicry, which have largely informed the maintenance of the status quo as relates to colonial institutional legacies, we have attempted to convey in our analysis the extent to which diffusion and institutional outcomes are mutually reinforcing. Using a constructivist framework, we have conveyed that ideas matter insofar as they are able to normalize particular institutional behaviours or catalyze certain institutional outcomes via these modes and methods of diffusion.

We have sought to present concrete examples of ideational diffusion and norm formation at work in the institutional context of Curaçao, Sint Maarten, and Trinidad and Tobago based on the lived experiences of our research participants. Based on our interpretation of the data, we have noted that responses to questions of norm acceptance, resistance or rejection in these territories were typically framed in the context of formal metropolitan dynamics in the case of Curaçao and Sint Maarten, and informal dynamics in the case of Trinidad and Tobago, which underpin colonial and postcolonial relationships, respectively. On one hand, because of its independence, Trinidad and Tobago was wellpositioned to resist or reject the diffusion of particular ideas and norms that were not amenable to context-relevant institution building. On the other hand, we observed the pervasiveness of diffusion mechanisms at work, despite the absence of formal colonial ties, which did not distinctively set it apart from the institutional modus operandi of the non-independent island territories. As a consequence, the Westminster-adapted model continues to be retained in the 
face of unsuccessful constitutional reform efforts. The narrative in the autonomous SNIJs, however, was one in which rejection and resistance were underlying sentiments, curtailed primarily by the necessity of belonging to much more complex and formal political and constitutional arrangements in the formation of the Kingdom of The Netherlands.

The most important point we wish to convey is that, based on our triangulation of the empirical data, the systematic and structural effect of norms and ideas in the institutional realm cannot solely be attributed to constitutional status but is instead more intricately linked to shared commonalities in terms of size, geography and common historical and sociocultural experiences.

\section{References}

Arthur, O. (2002). Towards a new governance. In S. Ryan \& A.M. Bissessar (Eds.). Governance in the Caribbean (pp. 32-36). St. Augustine: Sir Arthur Lewis Institute of Social and Economic Studies (SALISES), University of the West Indies.

Baldacchino, G., \& Milne, D. (2006). Exploring sub-national island jurisdictions: An editorial introduction. The Round Table, 95(4), 487-502. https://doi.org/10.1080/00358530600929735

Beckford, G. (1972). Persistent poverty: Underdevelopment in the plantation economies of the Third World. Oxford: Oxford University Press.

Beland, D. (2010). The idea of power and the role of ideas. Political Studies Review, 8(2), 145-154. Beland, D. (2009). Ideas, institutions, and policy change. Journal of European Public Policy, 16(5), 701-718. https://doi.org/10.1080/13501760902983382

Best, L., \& Levitt, K. (1969). Externally propelled growth and industrialization in the Caribbean. Montreal: Mimeo.

Bishop, M. (2011). Slaying the 'Westmonster' in the Caribbean? Constitutional reform in St. Vincent and the Grenadines. British Journal of Politics and International Relations, 13, 420437. https://doi.org/10.1111/j.1467-856x.2010.00432.x

Bissessar, A.M. (2002). The introduction of new public management in small states. In S. Ryan \& A.M. Bissessar (Eds.) Governance in the Caribbean (pp. 504-517). St. Augustine: Sir Arthur Lewis Institute of Social and Economic Studies (SALISES), University of the West Indies.

Corbett, J., \& Veenendaal, W. (2016). Westminster in small states: Comparing the Caribbean and Pacific experience. Contemporary Politics, 22(4), 432-449. https://doi.org/10.1080/13569775.2016.1175096

Daily Herald (2015). Financial supervision will remain in place. The Daily Herald, October 3. Retrieved from https://www.thedailyherald.sx/islands/financial-supervision-will-remain-in-place?

Demas, W. (2002). Public administration for sustained development. In S. Ryan \& A.M. Bissessar (Eds.). Governance in the Caribbean (pp. 457-466). St. Augustine: Sir Arthur Lewis Institute of Social and Economic Studies (SALISES), University of the West Indies. Dumas, R. (2002). Some issues in public service reform in Trinidad and Tobago. In S. Ryan, \& A.M. Bissessar (Eds.). Governance in the Caribbean (pp. 494-496). St. Augustine: Sir Arthur Lewis Institute of Social and Economic Studies (SALISES), University of the West Indies. 
Gallagher, J. (2014). Chopping the world into bits: Africa, the World Bank, and the good governance norm. International Theory, 6(02), 332-349. https://doi.org/10.1017/s1752971914000153

General Audit Chamber (2014). Baseline study Sint Maarten-State of affairs institutional integrity management. Philipsburg: General Audit Chamber.

Ghosh, A. (1996). Governance, institution-building and economic development. Economic and Political Weekly, 31(24), 1432-1433.

Gilardi, F. (2012). Transnational diffusion: Norms, ideas, and policies. In W. Carlsnaes, T. Risse \& B. Simmons (Eds.). Handbook of International Relations (pp. 453-477). Thousand Oaks: Sage. https://doi.org/10.4135/9781446247587.n18

Girvan, N. (2015). Assessing Westminster in the Caribbean: Then and now. Commonwealth and Comparative Politics, 53(1), 95-107. https://doi.org/10.1080/14662043.2014.993162

Holm, H.H., \& Sørensen, H. (eds.) (1995). Whose world order?: Uneven globalization and the end of the Cold War. Boulder: Westview.

Hopf, T. (2000). Constructivism all the way down. International Politics, 37(3), 369-378.

Hyden, G., Court, J., \& Mease, K. (2004). Making sense of governance: Empirical evidence from sixteen developing countries. Boulder: Lynne Rienner Publishers.

La Guerre, J. (2012). Constitutional design, good governance and political change in a plural society. In A.M. Bissessar (Ed.). Governance: Is it for everyone? (Chapter 8). New York: Nova Science.

La Guerre, J. (2002). National unity, the Westminster Model and governance in the Commonwealth Caribbean. In S. Ryan \& A.M. Bissessar (Eds.). Governance in the Caribbean (pp. 23-31). St. Augustine: Sir Arthur Lewis Institute of Social and Economic Studies (SALISES), University of the West Indies.

Landman, T. (2008). Issues and methods in comparative politics: An introduction. New York: Routledge.

Lenz, T. (2013). EU normative power and regionalism: Ideational diffusion and its limits. Cooperation and Conflict, 48(2), 211-228. https://doi.org/10.1177/0010836713485539

Lieberman, R. (2002). Ideas, institutions, and political order: Explaining political change. American Political Science Review, 96(4), 697-712. https://doi.org/10.1017/s0003055402000394

Lindsay, L. (1975). The myth of independence: Middle class politics and non-mobilization in Jamaica. Working Paper No. 6. Sir Arthur Lewis Institute of Social and Economic Studies (SALISES). https://doi.org/10.2139/ssrn.1822826

Manning, N. (2001). The legacy of New Public Management in developing countries. International Review of Administrative Science, 67(2), 297-312. https://doi.org/10.1177/0020852301672009

Netherlands Institute for Multiparty Democracy \& Instituut voor Publiek en Politiek (2008). The Dutch Political System in a Nutshell. The Hague \& Amsterdam: Netherlands Institute for Multiparty Democracy \& Instituut voor Publiek en Politiek.

Oostindie, G., \& Klinkers, I. (2003). Decolonising the Caribbean: Dutch policies in a comparative perspective. Amsterdam: Amsterdam University Press. 
Oostindie, G., \& Sutton, P. (2006). Small scale and quality of governance: A survey of the scholarly literature, with special reference to the Caribbean. The Hague: Ministerie van Binnenlandse Zaken en Koninkrijksrelaties.

Payne, A. (1993). Westminster adapted: The political order of the Commonwealth Caribbean. In J. Domínguez, R. Pastor \& W. DeLisle (Eds.). Democracy in the Caribbean: Political, economic, and social perspectives (pp. 57-73). Baltimore: Johns Hopkins University Press. https://doi.org/10.2307/165959

Pollitt, C. (1993). Managerialism and the public services. Oxford: Blackwell.

Quinn, K. (2015). Introduction: Revisiting Westminster in the Caribbean. Commonwealth and Comparative Politics, 53(1), 1-7. https://doi.org/10.1080/14662043.2014.993146

Ryan, S. (2002). Administrative improvement in the Commonwealth Caribbean. In S. Ryan \& A.M. Bissessar (Eds.). Governance in the Caribbean (pp. 439-456). St. Augustine: Sir Arthur Lewis Institute of Social and Economic Studies (SALISES), University of the West Indies.

Stone, D. (2012). Transfer and translation of policy. Policy Studies, 33(6), 483-499.

Today Newspaper (2016). Wescot-Williams proposes code of conduct to curb Shipjumping. Today Newspaper, September 19. Retrieved from https://web.archive.org/web/20190720155013/http://www.todaysxm.com/wescotwilliams-proposes-code-of-conduct-to-curb-ship-jumping/

Towns, A. (2012). Norms and social hierarchies: Understanding international policy diffusion "from below." International Organization, 66(2), 179-209.

Turner, M., Hulme., D. \& McCourt, W. (2015). Governance, management and development: Making the state work. New York: Palgrave Macmillan.

Veenendaal, W. (2016) Blog: Missed opportunities: Why Dutch institutions fail in the Caribbean. December 1. Retrieved from http://www.kitlv.nl/blog-missedopportunities-dutch-institutions-fail-caribbean/

Veenendaal, W. (2015). The Dutch Caribbean municipalities in comparative perspective. Island Studies Journal, 10 (1), 15-30. 